\title{
PENGARUH MODEL PEMBELAJARAN BERBASIS MASALAH BERBANTUAN VIDEO KARTUN TERHADAP HASIL BELAJAR FISIKA SISWA KELAS XI SMAN 1 SIKUR TAHUN AJARAN 2014/2015
}

\author{
Syayid QosimM. Jafar Al-idrus ${ }^{1}$, Hikmawati², Wahyudi ${ }^{2}$ \\ 1. Alumini Pendidikan Fisika FKIP Universitas Mataram \\ 2. Program Studi Pendidikan Fisika, FKIP Universitas Mataram \\ Email: hikmawati.fisika@yahoo.com
}

\begin{abstract}
Abstrak: Penelitian ini bertujuan untuk mengetahui pengaruh model pembelajaran berbasis masalah dengan bantuan video kartun terhadap hasil belajar fisika siswa. Jenis penelitian yang digunakan adalah quasi experimental. Populasi penelitian ini adalah seluruh siswa kelas XI IPA SMAN 1 Sikur tahun ajaran 2014/2015 dengan jumlah 113 siswa. Pengambilan sampel dilakukan melalui teknik purposive sampling dengan siswa kelas XI IPA 2 sebanyak 37 siswa sebagai kelas eksperimen dan siswa kelas XI IPA 1 sebanyak 36 siswa sebagai kelas kontrol. Desain yang digunakan dalam penelitian ini adalah nonequivalent control group design. Instrumen yang digunakan berupa tes tertulis dalam bentuk pilihan ganda yang sebelumnya dilakukan uji validitas, reliabilitas, analisis tingkat kesukaran, dan analisis daya beda soal. Data hasil tes akhir dianalisis menggunakan uji-t dua pihak dengan rumus pooled varians dan diperoleh thitung sebesar $(5,318)$ dengan tabel sebesar $(1,996)$ pada taraf signifikansi 5\%. Nilai thitung lebih besar dari tabel maka $\mathrm{H}_{0}$ ditolak dan Ha diterima. Hal ini menunjukkan bahwa model pembelajaran berbasis masalah berbantuan video kartun berpengaruh terhadap hasil belajar fisika siswa kelas XI SMAN 1 Sikur.
\end{abstract}

Kata kunci : Model pembelajaran berbasis masalah, video kartun, hasil belajar.

\begin{abstract}
This research aims to determine the effect of problem-based learning model assisted cartoon video of the physics student learning outcomes. This type of research is a quasi-experimental. The study population was all students (113 students) of class XI IPA SMAN 1 Sikur academic year 2014/2015. Sampling was done through purposive sampling technique with class XI IPA 2 as experimental class (37 students) and class XI IPA 1 as the control class ( 36 students). The nonequivalent control group was used as the experimental design. The instruments used in the form of a written test in the form of multiple choices previously tested the validity, reliability, analysis of the level of difficulty, and analysis about the different power. The final test result data were analyzed using $\mathrm{t}$-test two parties with pooled variance formula and obtained $t_{\text {count }}$ of (5.318) with $t_{\text {table }}$ of (1.996) at the 5\% significance level. The value of $t_{\text {count }}$ greater than $\mathrm{t}_{\text {table }}$ then $\mathrm{H}_{0}$ is rejected and $\mathrm{Ha}$ is accepted. This suggests that the problem-based learning model assisted cartoon video has effect on the student class XI of SMAN 1 Sikur physics learning outcomes.
\end{abstract}

Keywords: Problem-based learning model, video cartoon, learning outcomes.

\section{PENDAHULUAN}

Sumber daya manusia yang berkualitas adalah manusia yang mampu memahami pengetahuan dan mengaplikasikan pengetahuan tersebut dalam kehidupan sehari-hari yang bermanfaat bagi dirinya maupun masyarakat di sekitarnya. Sumber pengetahuan tersebut salah satunya diperoleh melalui jenjang pendidikan. Dengan demikian, salah satu upaya yang dapat dilakukan untuk menciptakan manusia yang berkualitas adalah dengan meningkatkan kualitas pendidikan. Salah satu ilmu pengetahuan yang mendasari perkembangan teknologi adalah ilmu pengetahuan alam (IPA). Fisika pada tingkat SMA/MA merupakan salah satu cabang IPA yang penting untuk diajarkan sebagai mata pelajaran sendiri karena memberikan bekal ilmu kepada peserta didik dan menumbuhkan kemampuan berpikir yang berguna untuk memecahkan masalah di dalam kehidupan sehari-hari serta dapat membekali peserta didik baik pengetahuan, pemahaman dan sejumlah kemampuan yang dipersyaratkan untuk memasuki jenjang pendidikan yang lebih tinggi [1]. Oleh karena itu, pembelajaran fisika di sekolah harus ditingkatkan dan dilaksanakan dengan baik agar dapat memberikan bekal kepada siswa sebagai landasan untuk dapat mengikuti perkembangan teknologi.
Keterlibatan siswa secara aktif dalam proses pembelajaran merupakan hal yang utama, namun pada kenyataanya pembelajaran fisika yang diterapkan di sekolah masih banyak berpusat pada guru. Pembelajaran yang berpusat pada guru tidak dapat membekali siswa dalam menyelesaikan masalah dalam kehidupan sehari-hari. Selain itu, pembelajaran yang hanya berpusat pada guru membuat siswa menjadi tidak tertarik untuk belajar fisika, sehingga berdampak pada hasil belajar fisika siswa yang rendah.

Berdasarkan observasi terhadap proses belajar mengajar yang dilakukan di kelas XI pada populasi penelitian ditemukan fakta-fakta bahwa pembelajaran yang dilakukan rata-rata masih berpusat pada guru. Guru lebih aktif menyampaikan informasi, sedangkan siswa pasif dan hanya menerima informasi, sehingga siswa tidak memiliki kemampuan untuk berpikir kritis dan menggali informasi yang diterimanya. Hal ini menyebabkan siswa kurang menguasai konsep-konsep fisika. Selain itu juga diperoleh data bahwa nilai siswa masih di bawah kriteria ketuntasan minimum (KKM) yakni 77. Hal ini jelas membuktikan bahwa pembelajaran yang hanya berpusat pada guru tidak dapat menarik minat siswa dalam mengikuti pelajaran fisika. 
Salah satu model pembelajaran yang dipandang dapat membantu dan menarik rasa keingintahuan siswa adalah model Pembelajaran Berbasis Masalah. Pembelajaran berbasis masalah memusatkan pada masalah kehidupannya yang bermakna bagi siswa, peran guru menyajikan masalah, mengajukan pertanyaan, dan memfasilitasi penyelidikan dan dialog [2]. Dalam model pembelajaran berbasis masalah, siswa tidak sekedar dapat mengingat materi pelajaran, tetapi siswa dapat menguasai materi pelajaran secara penuh.

Selain menggunakan model pembelajaran, media juga mempunyai peranan yang sangat penting. Penggunaan media pembelajaran tentunya dapat membuat siswa menjadi lebih tertarik dan berminat untuk belajar fisika. Salah satu media yang digunakan untuk menyampaikan suatu pesan mengenai masalah fisika dalam keseharian adalah media video kartun. Media audio-visual merupakan media yang mengkombinasikan materi auditif yang merangsang pendengaran dan materi visual yang merangsang penglihatan [3]. Kartun merupakan penggambaran dalam bentuk lukisan atau karikatur tentang orang, gagasan atau situasi yang didesain untuk mempengaruhi opini masyarakat [4]. Dengan kombinasi kedua materi ini, pendidik dapat menciptakan proses pembelajaran yang lebih berkualitas, mampu mencapai efektivitas proses pembelajaran, mengarahkan perhatian murid untuk berkonsentrasi pada materi yang dipelajari sehingga poses pembelajaran menjadi menarik, serta memberikan pengalaman langsung kepada siswa tentang suatu kejadian atau peristiwa. Dengan demikian perpaduan antara model pembelajaran berbasis masalah dan media video kartun diharapkan dapat mempengaruhi peningkatkan hasil belajar fisika siswa.

\section{METODE PENELITIAN}

Penelitian ini dilaksanakan pada kelas XI SMAN 1 Sikur tahun ajaran 2014/2015. Jenis penelitian ini adalah penelitian quasi eksperimen yaitu metode penelitian yang tidak memungkinkan adanya random untuk menetapkan kelompok perlakuan dan kelompok kontrol [5]. Penelitian ini dilaksanakan pada semester I dari tanggal 26 Agustus sampai tanggal 7 Oktober 2014. Desain penelitian menggunakan Nonequivalent Control Group Design. Adapun teknik pengambilan sampel yang digunakan adalah purposive sampling, yaitu teknik pengambilan sampel dengan alasan-alasan tertentu. Sampel penelitian ini adalah 73 siswa yang terbagi dalam dua kelas yaitu, kelas XIIPA 2 sebagai kelas eksperimen dan XI-IPA 1 sebagai kelas kontrol. Kelas eksperimen diberikan perlakuan dengan menggunakan model pembelajaran berbasis masalah berbantuan media video kartun dan kelas kontrol menggunakan model pembelajaran berbasis masalah saja.

$\begin{array}{ccc}\text { Prosedur } & \text { dan langkah-langkah yang } \\ \text { digunakan dalam melaksanakan penelitian ini }\end{array}$

mengikuti langkah-langkah pada model pembelajaran berbasis masalah dengan berbantuan video kartun di awal pelajaran. Video kartun sendiri menampilkan permasalahan yang sesuai dengan kehidupan seharihari siswa. Permasalahan yang dikaji dalam penelitian ini adalah hasil belajar fisika siswa. Agar dapat mengatasi permasalahan tersebut dilakukan tindakan berupa penggunaan model pembelajaran berbasis masalah dengan berbantuan video kartun pada materi usaha dan energi untuk meningkatkan hasil belajar fisika siswa.

Pada penelitian ini ada tiga variabel yang menjadi fokus penelitian yaitu variabel bebas, variabel kontrol, dan variabel terikat. Variabel bebas pada penelitian ini adalah model pembelajaran berbasis masalah berbantuan video kartun, variabel terikat adalah hasil belajar fisika siswa, dan variabel kontrol kemampuan awal kelas eksperimen dan kelas kontrol dianggap sama yakni guru, materi, tujuan pembelajaran, instrumen, alokasi waktu, dan cara penilaian.. Teknik pengumpulan data pada penelitian ini adalah tes hasil belajar. Data hasil belajar merupakan data tes awal sebelum diberikan perlakuan dan tes akhir yang dilakukan setelah perlakuan. Data tes awal (pretest) dan tes akhir (posttest) diperoleh dengan menggunakan instrumen yang telah diujicobakan kepada 36 orang siswa kelas XII di SMAN 1 Sikur tahun ajaran 2014/2015 yang diukur dengan uji validitas, reliabilitas, tingkat kesukaran, dan daya beda soal. Berdasarkan hasil uji coba 40 butir soal materi usaha dan energi diperoleh 30 soal yang baik digunakan untuk pretest dan posttest. Analisis valiiditas instrumen menggunakan rumus product moment untuk menguji validitas soal dan KR-20 untuk uji reliabilitas soal. Analisis data tes akhir menggunakan uji-t dua pihak.

\section{HASIL DAN PEMBAHASAN}

Hasil penelitian berupa deskripsi hasil tes awal dan tes akhir dengan menggunakan uji homogenitas, uji normalitas dan uji hipotesis (uji-t dua pihak). Data tes awal digunakan untuk mengetahui keadaan awal kelas, dan data tes akhir digunakan untuk mengetahui ada tidaknya perbedaan hasil belajar siswa setelah diberikan perlakuan yang berbeda, sehingga dari perbedaan tersebut dapat dilihat pengaruh dari pembelajaran berbasis masalah berbantuan video kartun terhadap hasil belajar fisika. Adapun hasil rekapitulasi nilai tes awal dan tes akhir pada kelas eksperimen dan kelas kontrol materi usaha dan energi dapat dilihat pada tabel berikut.

Sesuai dengan perencanaan penelitian, kegiatan pembelajaran dilakukan sebanyak lima kali pertemuan, terdiri dari tiga kali tatap muka di kelas dalam proses pembelajaran dan dua kali pertemuan untuk tes awal dan tes akhir baik kelas kontrol maupun kelas eksperimen. Kelas XI-IPA 2 sebagai kelas eksperimen peneliti menerapkan model pembelajaran berbasis masalah berbantuan video kartun, sedangakan pada kelas XI-IPA 1 sebagai kelas kontrol 
menggunakan model pembelajaran berbasis malasah biasa.

Tabel 1. Rekapitulasi nilai tes awal pada kelas eksperimen dan kelas kontrol materi usaha dan energi

\begin{tabular}{|l|c|c|}
\hline \multirow{2}{*}{ Komponen } & \multicolumn{2}{|c|}{ Kemampuan Awal (Pretest) } \\
\cline { 2 - 3 } & $\begin{array}{c}\text { Kelas } \\
\text { Eksperimen }\end{array}$ & $\begin{array}{c}\text { Kelas } \\
\text { Kontrol }\end{array}$ \\
\hline Jumlah siswa & 37 & 36 \\
\hline Nilai tertinggi & 50 & 57 \\
\hline Nilai terendah & 10 & 17 \\
\hline Rata-rata & 28,47 & 33,98 \\
\hline Standar Deviasi(SD) & 10,62 & 8,72 \\
\hline Uji Homogenitas & \multicolumn{2}{|c|}{ Homogen } \\
\hline
\end{tabular}

Tabel 2. Rekapitulasi nilai tes akhir pada kelas eksperimen dan kelas kontrol materi usaha dan energi

\begin{tabular}{|l|c|c|}
\hline \multirow{2}{*}{\multicolumn{1}{|c|}{ Komponen }} & \multicolumn{2}{c|}{$\begin{array}{c}\text { Kemampuan Awal } \\
\text { (Pretest) }\end{array}$} \\
\cline { 2 - 3 } & $\begin{array}{c}\text { Kelas } \\
\text { Eksperimen }\end{array}$ & $\begin{array}{c}\text { Kelas } \\
\text { Kontrol }\end{array}$ \\
\hline Jumlah siswa & 37 & 36 \\
\hline Nilai tertinggi & 80 & 70 \\
\hline Nilai terendah & 43 & 30 \\
\hline Rata-rata & 61,44 & 47,91 \\
\hline Standar Deviasi(SD) & 8,91 & 9,51 \\
\hline Uji Homogenitas & \multicolumn{2}{|c|}{ Homogen } \\
\hline Uji Normalitas & Normal & Normal \\
\hline Uji Hipotesis & \multicolumn{2}{|c|}{$t_{\text {titung }}>t_{\text {tabel }}=$ Ha } \\
& \multicolumn{2}{|c|}{ diterima } \\
\hline
\end{tabular}

Pada pertemuan pertama dilakukan tes awal sesuai dengan desain penelitian pada kedua kelas. Tes awal digunakan untuk mengetahui keadaan awal kedua kelas. Hasil dari tes awal menunjukkan data yang homogen. Sehingga dapat disimpulkan bahwa tidak terdapat perbedaan hasil belajar antara kelompok kelas eksperimen dan kelas kontrol, yang berarti bahwa kemampuan kedua kelas adalah sama. Kedua kelas memenuhi syarat dijadikan sampel penelitian karena kedua kelas memiliki keadaan hasil belajar yang sama. Oleh sebab itu, penelitian dapat dilanjutkan ke tahap selanjutnya.

Hasil tes akhir yang telah dilakukan selanjutnya dilakukan uji hipotesis untuk melihat signifikansi perbedaan hasil belajar ke dua kelas. Hasil uji hipotesis yang dilakukan membuktikan terdapat perbedaaan hasil belajar fisika antara kelas kontrol dan kelas eksperimen. Terlihat dari uji-t dua pihak menunjukan $t_{\text {hitung }} 5,318$ sedangkan $\mathrm{t}_{\text {tabel }} 1,996$. Temuan ini menunjukan bahwa Ho berada pada daerah penolakan terlihat bahwa nilai $t_{\text {hitung }}>t_{\text {tabel }}$, yakni $5,318>1,996$ pada taraf signifikansi 5\%, sehingga Ha diteima dan $\mathrm{H}_{0}$ ditolak. Uji-t dua pihak menggambarkan signifikansi perbedaan hasil belajar fisika antara siswa yang diajar dengan model pembelajaran berbasis masalah berbantuan video kartun dengan siswa yang diajar dengan model pembelajaran berbasis masalah biasa. Perbedaan yang berarti (signifikan) yang telah ditemukan dari hasil tes akhir kelas eksperimen dan kelas kontrol menunjukan pengaruh dari perlakuan yang diberikan pada kedua kelas tersebut. Perbedaan ini menunjukan bahwa terdapat pengaruh model pembelajaran berbasis masalah terhadap hasil belajar fisika pada siswa kelas XI SMAN 1 Sikur.

Berkenaan dengan hasil tes akhir, diperoleh hasil belajar pada kelompok eksperimen memiliki ratarata kelas sebesar 61,44 sedangkan kelompok kontrol memiliki rata-rata kelas sebesar 49,91. Hal ini menunjukkan bahwa kelompok siswa yang mengikuti mengunakan model pembelajaran berbasis masalah berbantuan video kartun mempunyai hasil belajar yang lebih baik (kelas eksperimen) dibandingkan dengan kelompok siswa yang mengikuti model pembelajaran berbasis masalah (kelas kontrol).

Temuan lain yang diperolah selama penelitian adalah permasalahan yang disajikan melalui media video kartun untuk menampilkan kejadian sehari-hari dapat merangsang antusias siswa untuk memecahkan masalah dan aktif dalam melakukan penyelidikan. Temuan ini diperkuat oleh data nilai ratarata siswa pada ranah afektif dan psikomotor sebesar 77,19 dan 91,83 . Video kartun sendiri dapat menarik minat, memotivasi dan menarik perhatian siswa dalam mengikuti pembelajaran. Hal ini sesuai dengan penelitian sebelumnya yang menyatakan bahwa penggunaan media kartun berpengaruh terhadap motivasi dan hasil belajar siswa [6]. Hasil penelitan lain juga menyimpulkan bahwa media video kartun berpengaruh signifikan terhadap peningkatan motivasi dan hasil belajar siswa [7].

Model pembelajaran berbasis masalah mengharuskan siswa berhadapkan dengan permasalahan dunia nyata sebagai sesuatu yang harus dipelajari untuk meningkatkan kemampuan berpikir, kemampuan memecahkan masalah, dan untuk mendapatkan pengetahuan mengenai konsep-konsep penting dalam ilmu fisika. Model ini mengharuskan siswa untuk menemukan dan menggali informasi sendiri bukan lagi sebagai penerima informasi. Dalam kegiatan penelitian ini, diawali dengan penyajian masalah berkaitan dengan kehidupan sehari-hari kepada siswa menggunakan video kartun, yang selanjutnya dalam proses penyelesaian masalah tersebut menggunakan lembar kerja siswa sebagi petunjuk untuk memecahkan permasalahan yang diberikan. Selanjutnya setelah siswa melakukan percobaan peneliti membimbing siswa untuk menarik kesimpulan dari permasalahan yang diberikan. Setelah itu, peneliti membantu siswa untuk menyajikan persentasi hasil diskusi kelompoknya. Tahap akhir siswa bersama dengan penliti membandingkan hasil pemecahan masalah yang telah dilakukan oleh siswa dengan pemecahan masalah yang dilakukan oleh para ahli atau dengan konsep yang sebenarnya. Sehingga dengan menggunakan model pembelajaran berbasis masalah dengan bantuan media video kartun memberikan pengaruh yang positif terhadap hasil 
belajar fisika siswa yakni terlihat dari peningkatan hasil belajar fisika siswa.

Hasil penelitian ini diperkuat oleh beberapa teori yang menyatakan bahwa pembelajaran berbasis masalah adalah suatu pendekatan pembelajaran yang menggunakan masalah dunia nyata sebagai suatu konteks bagi siswa untuk belajar tentang berpikir kritis dan keterampilan pemecahan masalah serta untuk memperoleh pengetahuan dan konsep yang esensi dari materi pelajaran [8]. Melalui model ini, siswa dapat memperoleh pengetahuan dengan melakukan kegiatan pemecahan masalah sehingga konsep yang dipelajari dapat diterima dan memahami informasi yang telah diterima serta menghubungkannya dengan kehidupan sehari-hari. Dengan demikian, siswa tidak hanya mengusai teori saja akan tetapi dapat mengaplikasikan apa yang mereka pelajari tersebut dalam kehidupan sehari-hari. Hal ini memperkuat teori bahwa model pembelajaran berbasis masalah adalah interaksi antara stimulus dan respons, merupakan hubungan antara dua arah belajar dan lingkungan [9]. Adapun penelitian sebelumnya yang mendukung penelitian ini menunjukkan bahwa dengan menerapkan model pembelajaran berbasis masalah dapat meningkatkan aktifitas dan hasil belajar siswa [10]. Hasil penelitan lain juga menyatakan bahwa dengan menerapkan model pembelajaran berbasis masalah disimpulkan terdapat perbedaan yang signifikan antara rata-rata skor tes akhir kelas eksperimen dengan kelas kontrol pada siswa kelas XI SMAN 5 Palu [11].

Dari hasil penelitian ini dapat dikatakan bahwa model pembelajaran berbasis masalah berbantuan video kartun dapat memberikan pengaruh positif terhadap hasil belajar fisika siswa. Jadi, dalam kegiatan belajar mengajar, guru dapat menerapkan model model pembelajaran berbasis masalah dengan bantuan media video kartun untuk dijadikan sebagai salah satu alternatif model pembelajaran yang dapat diterapkan, karena sebagai seorang guru harus mampu memilih dan menggunakan model pembelajaran yang tepat untuk diterapkan pada siswa dan keadaan di lingkungan sekolah.

\section{KESIMPULAN DAN SARAN}

Berdasarkan hasil penelitian dan pembahasan maka dapat disimpulkan bahwa pembelajaran fisika menggunakan model pembelajaran berbasis masalah berbantuan video kartun berpengaruh terhadap hasil belajar fisika siswa SMAN 1 Sikur tahun ajaran 2014/2015. Hal ini dibuktikan oleh hasil belajar fisika siswa yang diajarkan dengan model pembelajaran berbasis masalah berbantuan video kartun lebih tinggi dari pada hasil belajar siswa yang diajarkan model pembelajaran berbasis masalah biasa.

Model pembelajaran berbasis masalah berbantuan video dapat dijadikan sebagai alternatif bagi pengajar untuk diterapkan di dalam kelas. Dengan Penggunaan video kartun sebagai salah satu media dalam penerapan pembelajaran berbasis masalah dapat menarik minat dan merangsang siswa untuk lebih memperhatikan masalah yang diberikan, sehingga siswa akan lebih mengerti masalah yeng diberikan dan kegiatan pembelajaran lebih terarah.

\section{DAFTAR PUSTAKA}

[1] Badan Standar Nasional Pendidikan. 2006. Standar Isi Untuk Satuan Pendidikan Dasar dan Menengah: Standar Kompetensi dan Kompetensi Dasar SMA/MA. Jakarta : Badan Standar Nasional Pendidikan.

[2] Jauhar, M. 2011. Implementasi PAIKEM dari Behavioristik sampai Konstrutivistik. Jakarta: Prestasi Pustakaraya.

[3] Prastowo, A. 2012. Panduan Kreatif Membuat Bahan Ajar Inovatif. Jogjakarta: DIVA Press.

[4] Sujana N. dan Rivai A. 2011. Media Pengajaran. Bandung: Sinar Baru Algensindo.

[5] Setyosari, P. 2012. Metode Penelitian Pendidikan dan Pengembangan. Jakarta: Kencana Prenada Media Group.

[6] Kadek. S dan Sukoco. 2013. Pengaruh Media Kartun Terhadap Hasil Belajar Dan Motivasi Belajar Siswa Materi Sistem Kelistrikan Otomotif. Jurnal Pendidikan Vokasi Universitas Negeri Yogyakarta. Tidak diterbitkan.

[7] Wulandari, S. 2013. Pengaruh Media Video Kartun Dengan Dubbing Terhadap Motivasi Dan Hasil Belajar Siswa Pada Materi Pengelolaan Lingkungan Kelas VII Smp Negeri 1 Karangtengah Tahun Ajaran 2012/2013. Skripsi Jurusan Biologi Fakultas Pendidikan MIPA IKIP PGRI Semarang. Tidak diterbitkan.

[8] Rusman. 2012. Model-Model Pembelajaran Mengembangkan Profesionalisme Guru. Jakarta: Rajawali Pers.

[9] Trianto. 2007. Model-Model Pembelajaran Inovatif Berorientasi Konstruktivistik. Jakarta: Prestasi Pustaka.

[10] Kharida, L. A., 2009. Penerapan Model Pembelajaran Berbasis Masalah Untuk Peningkatan Hasil Belajar Siswa Pada Pokok Bahasan Elastisitas Bahan. Jurnal Pendidikan Fisika Indonesia Universitas Negeri Semarang. Tidak diterbitkan.

[11] Ashad, M., 2013. Pengaruh Model Pembelajaran Berbasis Masalah terhadap Hasil Belajar Fisika pada Siswa Kelas XI Sma Negeri 5 Palu. Jurnal Pendidikan Fisika Tadulako Universita Tadaluko Palu. Tidak diterbitkan. 